\title{
CURRENT BIOSYSTEMATIC RESEARCH ON DIATOMS AND ITS IMPLICATIONS FOR THE SPECIES CONCEPT
}

\section{H. Lange-Bertalot}

Botanisches Institut der J.W. Goethe-Universitat Frankfurt a.M, D 6000 Frankfurt a.M., Siesmayerstraße 70

Keywords: systematic, diatoms, species concept.

\begin{abstract}
In theory we ought to use two categories of diatom species: 1) real species in the sense of population biology, and 2) taxonomic or typological species. In practice, however, we seldom discriminate between these categories. This is the source of conflicts about indistinct, inadequate species concepts. There is no evidence to assume the real species are not the same here as in higher biparental plants, i.e. a community sharing the same gene pool. In unicellular algae, however, both categories of species disagree more often, since fewer taxonomically significant features can be distinguished. Two strategies of research will help to get an advanced standard comparable with higher plants:

1) To find out, by means of population analyses, the real panmictic capacities of various especies, polymorphic variations or races in question». Do polyploid clones or populations and complexes of uniparental hybrid clones exist around original sexual species? If so, the variations of such groups would not adequately be defined as biological species and this concept needs to be modified.

2) Irrespectively thereof, in order to achieve an approach to real species, historically developed taxa presuppose much more critical reflection than was used traditionally.
\end{abstract}

\section{INTRODUCTION}

As authors of a comprehensive Diatom-Flora (KRAMMER \& LANGE-Bertalot, 1986, 1988) our problem is to pay attention to an overburdening flood of taxa.

To give one example of the genus Nitzschia:

Each of the figures of plates 1 and 2 represents a typological Nitzschia species from different continents or regions photographed from the type materials (LANGE-BeRTALOT, 1977). The taxonomically earliest one is demonstrated by fig. 1:1. It can vary in a culture from such a representative, commonly well known form to such a tiny one as shown by fig. 1:9. To the extent that they can be observed by the electron microscope, we find uniformity. Neither Scanning - nor TransmissionEM - analyses are appropriate to help us effectively to discern different characters in such a group

Limnetica, 6: 13-22 (1990)

(C) Asociación Española de Limnología, Madrid, Spain of taxa. Even the arrangement of the cribra in the areolae (fig. 1:10) —-which may serve for a certain differentiation in other species groups of the genus - is uniform. Plate 2 shows more of single representatives of practically indeterminable, indefinable taxa, all on the species level, created not very long ago.

Othenvise the collection of plates 3 and 4 contains individuals of only one supposed species - or may be more; it is a sample of less than one teaspoon full, scraped from some square-centimeters of river-bank of the Loire, in France.

\section{REMARKS}

Conventional species creation has led us into a dilemma of vast proliferation of taxa. Minor problems at the beginning, in the last century; almost insolvable problems now. This is mainly because 


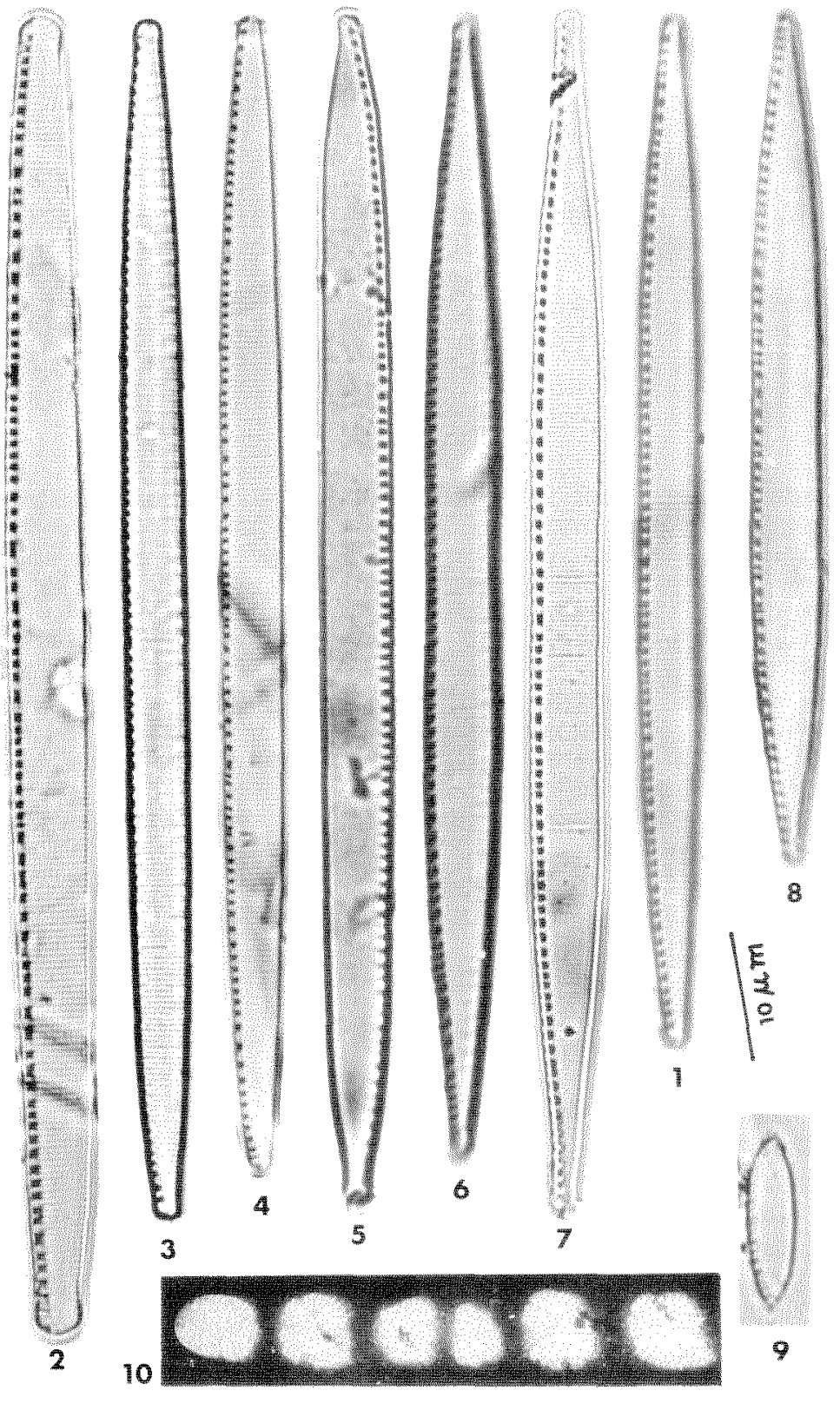

Plate $1(\times 1500$, TEM fig $10 \times 68000)$, Conformity (monotony) in a range of typological taxa in tbe Nitzschia secton «Lanceolatae» Fig 1-8 represent different typological spectes taken from type materials Fig 1 represents the taxonomically earliest one. Nitzschia intermedia Hantzsch 1880 In the life cycle of Nizschia internedia, however, occur also tuny specmens as un fig 9 The same or at least comparable variability must he presupposed in the life cycle of the other taxa demonstrated here which are less well known Fig 10 shows the typical uniform pattern of the perforated membranes (velum or hymen) closing the foramina of areolae

Conformidad (monotonia) en un rango de taxones tipologicos de la seccon «Lanceolatae» de Nizzchia Fig 1-8 Diferentes especes tipologicas sacadas de materiales tupo La figura 1 representa la mas antigua taxonomicamente, $N$ intermedia Hantzsch 1880 Sin embargo, en su ciclo de vida aparecen también ejemplares delgados corno los de la figura 9 Debería presuponerse una varubilidad igual o al menos. comparable en el ciclo vital de otros taxones referidos aqu que son menos conocidos La figura 10 muestra el tipico modelo uniforme de membrana perforada (velum o himen cerrando los foramina de areolas 


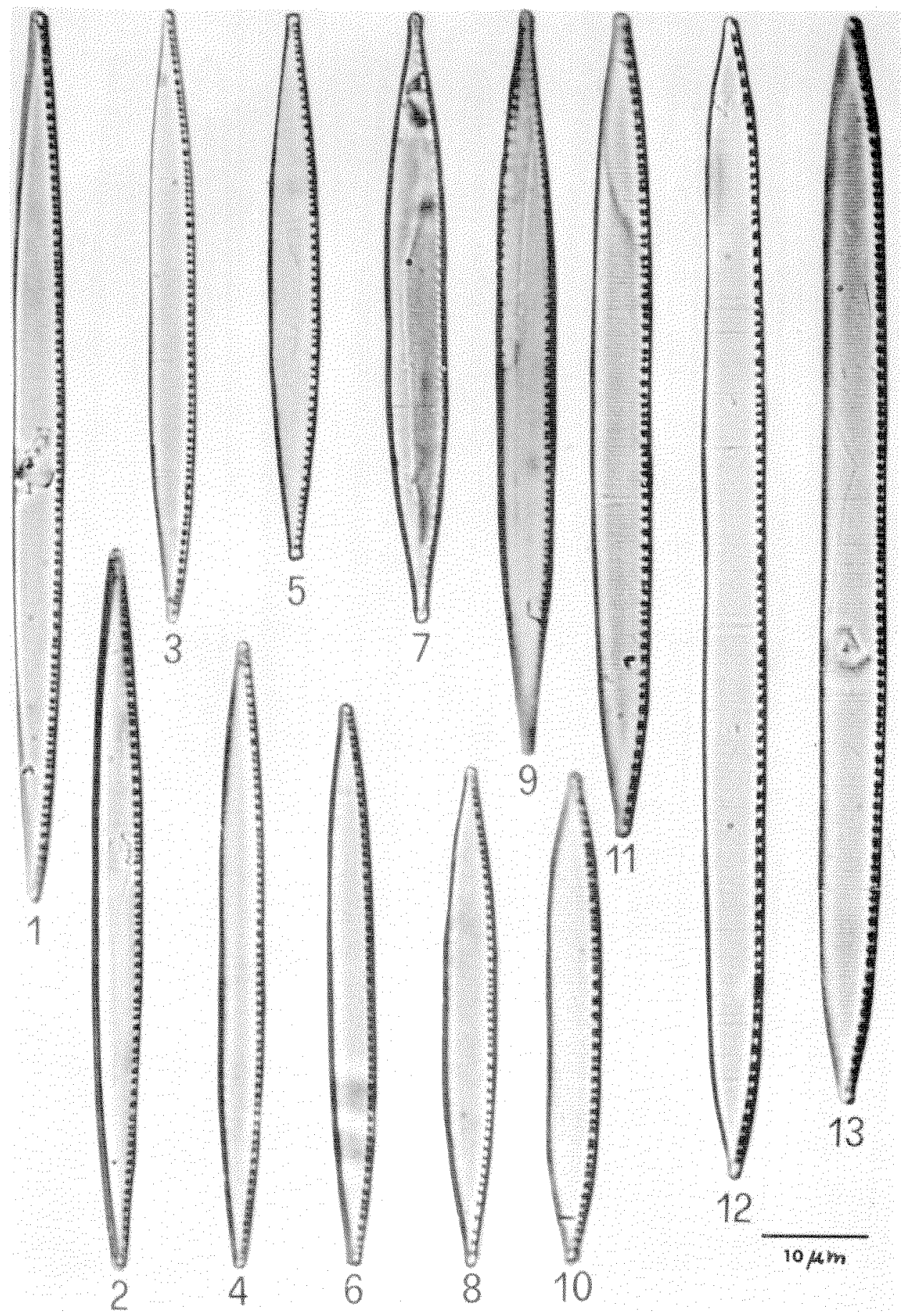

Plate 2: ( 1500$)$ Fig. 1-12 represent other examples of different typological species in the Nitzschia section «Lanceolatae". No one possesses morphological characteristics which may reliably serve to decide where the species boundaries lie.

Fig. 1-12: Otros ejemplos de especies tipológicas diferentes de la sección «Lanceolatae de Nitzschia. Ninguna posee caracteristicas morfológicas que permitan decidir donde se encuentran tos limites que marcan la separación entre especies. 


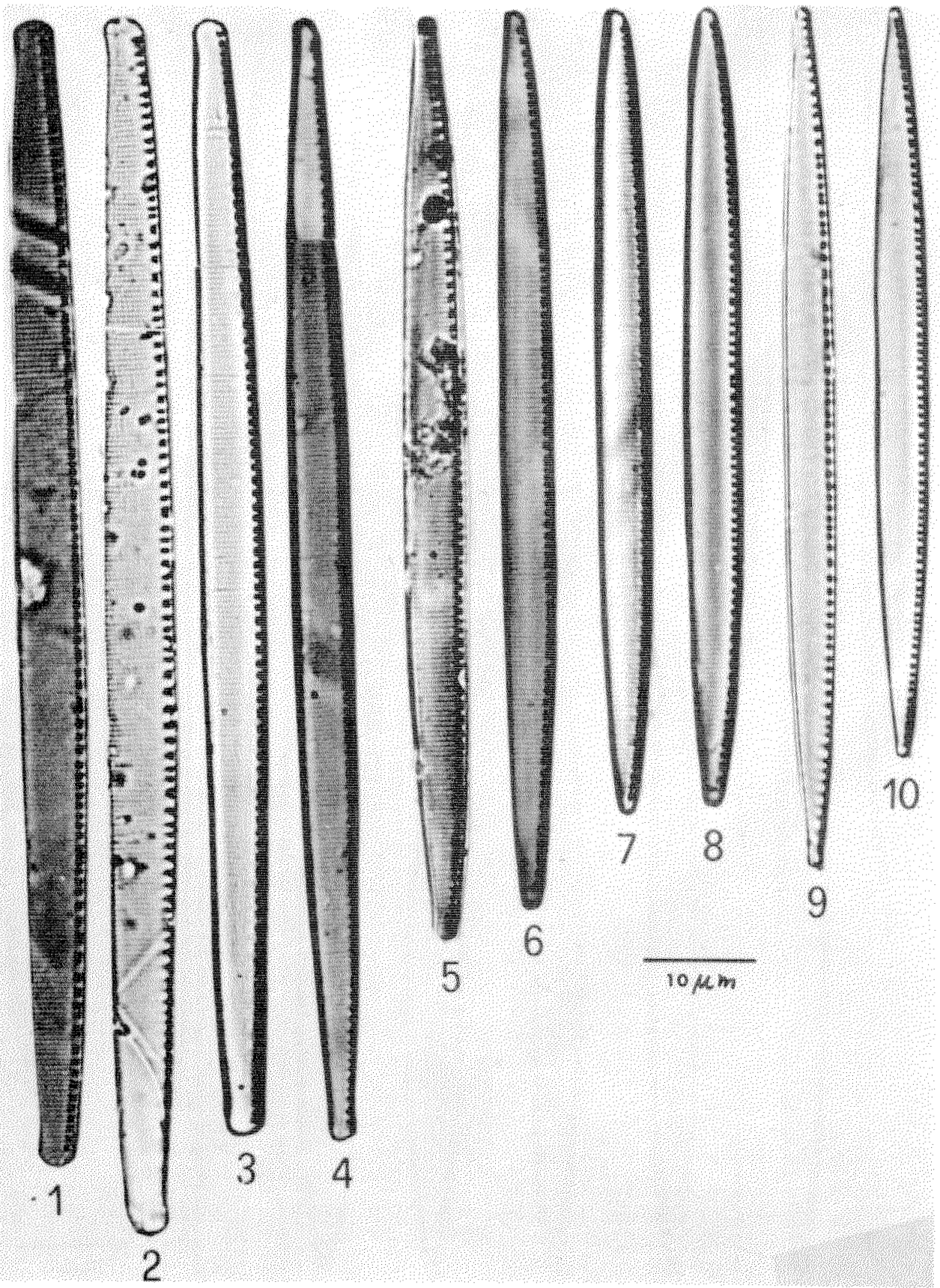

Plate 3 ( $\times 1500$ ), continued on Plate 4 Range of individuals of only one supposed spectes Nitzschia intemedia (c) Fig 1 and 9) all included in one sample from some square-centmeters of river-bank of the Loire in France

Grupo de individuos de una supuesta unca especte, Nitzschia intermedia (cf fig $1 \mathbb{1}$ y 9 ) todas ellas proceden de una misma mues tra de unos pocos centímetros cuadrados de la orilla del Loira, en Francia 


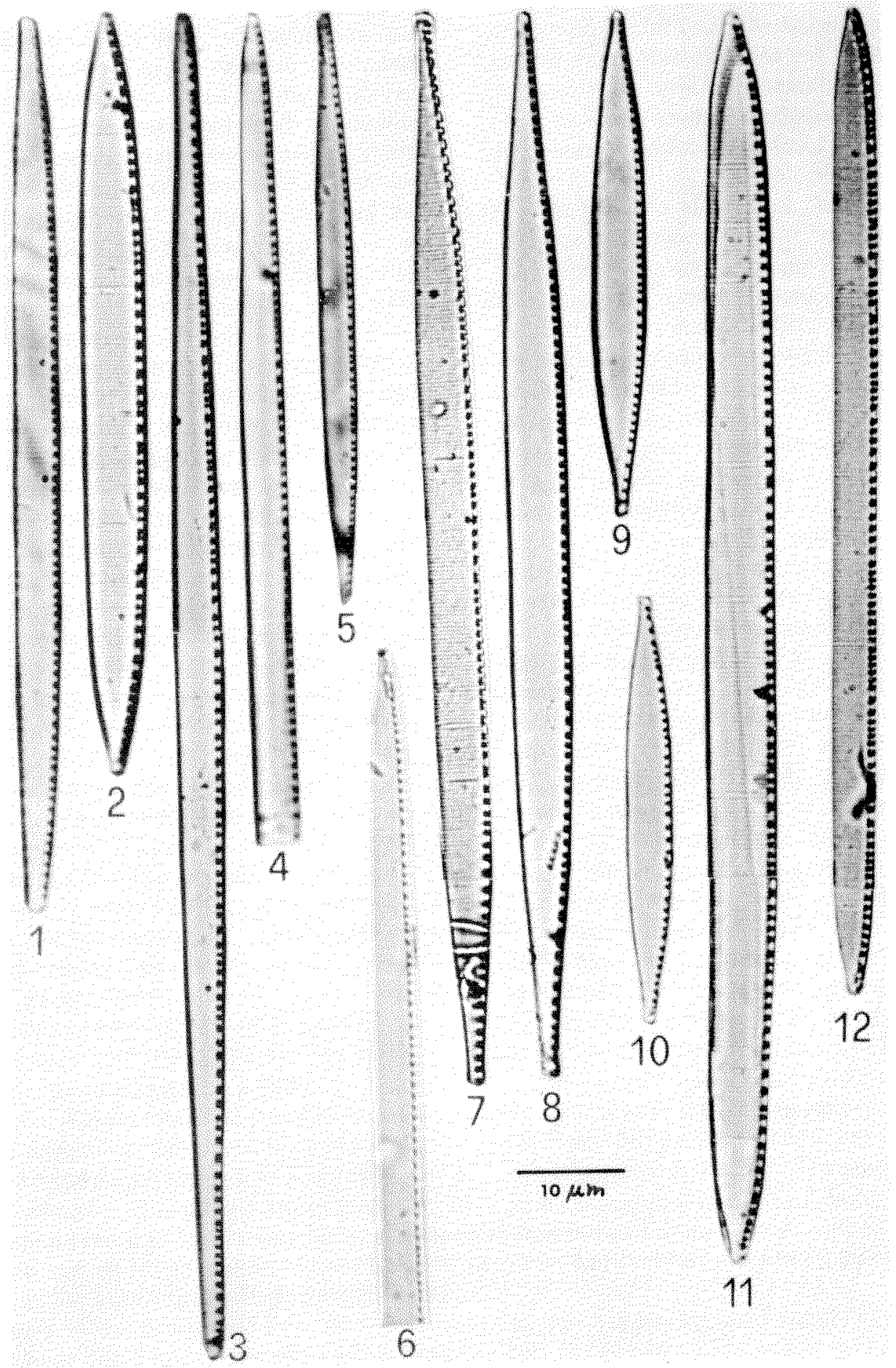


differences which have formerly been regarded as sufficient for species differentiation become successively smaller and smaller and finally disappear as criteria suitable for identification. Any taxonomic limitation on the species level must become arbitrary in such continous ranges of forms, unless the naming of local populations or clones or individuals is desired.

Diatom taxa which we usually consider as species are abstractions from presumable real species. Indeed each and all are based on one single or a small number of individuals while as biosystematic unities they are subject to extensive subjective assessment. This is the source of conflicts about indistinct, inadequate species concepts in various classes of unicellular organisms. In theory we ought to differentiate between 2 categories: 1 ) real species in the sense of population biology; 2) taxonomic or typological species, unfortunately also termed morphospecies.

In practice, however, we seldom discriminate between these categories. What actually occurs in each biotope is the presence of individuals. By far the greater majority of these are clonally derived individuals, which arise from successive vegetative reproduction by binary division. Individuals are much less frequently produced from a single parent by autogamy or apomixis (for instance parthenogenesis), or, as is usually the case in higher plants, directly from a biparental zygote. Together all such offspring, which are actually or potentially inter-fertile, build communities sharing the same gene pool. They should be reproductively isolated from other similar populations. The problem with the diatoms is that the population and the species boundaries remain obscure because regular monitoring of their sexual behaviour in nature on a worldwide basis is not feasible. Crossing and breeding experiments are bound to a necessarily elaborate, often unsuccessful methodology. Nevertheless only this can provide a fundamental starting point for understanding species in terms of population biology and evolutionary theory. The resulting entity is the so-called biological species.

This is the first of two fundamentally different research approaches which are recognised in the systematic treatment of organisms and for diatoms in particular.

The second is the inductive method: as far as diatoms are concerned this is traditionally based on light-microscopical comparisons of valve outlines and structure, since other classificatory methods, e.g. with the aid of protoplasmic features, have been shown to be extremely inadequate or (at least for the present) impracticable. This is particularly the case when paleobotanical aspects are involved. The systematic units delimited in this way must be considered morphospecies, in the sense of Ernest Mayr (MAYR, 1975). The most important methodological criteria on which they are defined are similarity and difference. The question is, whether the two approaches lead us to equivalent entities or not. Algologists firmly believe, or vaguely hope, that ultimately all visible features of the diatoms themselves will reveal where the species boundaries lie. Certainly, morphologic features are rarely isolation-relevant. However, if important as constructive elements, they demonstrate the result of biological adaptation. Thus, they are no less relevant than other secondary, which means indirect, criteria of a biospecies, for instance non-sexual behaviour or physiology. According to Mayr, on the basis of a number and specificity of morphological differences, one should be able to find an «indicator» of reproductive isolation; that means features which allow the deduction of such to be traced. That is a minor problem in higher organized organisms. Whether or not this is possible in certain unicellular organisms, where such significant features can hardly be detected, is still under discussion. Normally they can be found more or less clearly between genera and taxonomical species groups. The question arises as to whether Mayr's advice, as such, is helpful for diatom taxonomists with respect to the species level. We suggest that the chance of finding a taxonomic species in good accordance with a real species is high. Thus, if many individuals of all developmental stages of their peculiar life cycle and many populations from different localities are the basis of a taxon. The taxon then is to be understood as a well founded hypothetical species, which might be confirmed or refuted. However, the probability is low if a taxon is based on very few specimens or even tends to zero if only one specimen is the random sample in discussion.

It is however interesting that successful crossing experiments can produce contradictory results 
compared to morphological «character taxonomy». Thus GeITLER (1973) discovered barriers to cross-fertilization between microspecies within one morphospecies. This indicates approaching twin-species, which contain sexually isolated but morphologically identical units. Conversely, polymorphism can occur in plant species: similar to the example of the domestic dog with its interbreeding races. This, projected upon the conventional diatom morphospecies, would undoubtedly lead to their being awarded the status of species.

Another, opposite example in the animal kingdom is the brown trout. Formerly isolated races with different morphological characteristics could be induced by fishery interests to interbreed towards an undifferentiated race-mixture. On the other hand, among the brown seaweed Ectocarpus siliculosus, populations from European and American coasts are not inter-fertile, though morphologically completely identical.

Various opinions are held by biologists with a background in recognition theory as to whether a strict separation between the typological and population biological species definitions is absolutely necessary, or whether the typological species concept with the addition of biological information does not ultimately also lead to recognition of the true species. Even the biological species concept has its very weak points. In particular its application to groups of organisms which lack strict biparental reproduction is not without problems, and must be modified or superseded by using other concepts, in particular the syngameon theory of the Dutch botanist Lotsy, published in 1916 and 1925, almost forgotten later on and discussed again by GRANT (1976) with reference to higher plants. The ability to cross is the criterion for a syngameon and not the existence or absence of isolation mechanisms, in contrast with the biospecies.

Autogamy and apomixis have been detected in various diatom taxa. But very little is known about morphological or other biological consequences which, however, might be important biosystematically with regard to reduced panmixis. Nothing is known of phenomena such as polyploid complexes or hybridism. All these phenomena are well known in higher plants and also in various cryptogamic groups. Conspicuous consequences arise to the biospecies concept, since complexes of unipar- ental hybrid clones, microspecies and semispecies accompany the original sexual species. This is obvious in many angiosperms such as Hieracium, Crepis, Rubus, Citrus. They exhibit high genetic uniformity compensated for by rich modification capacities, in particular as pioneer plants from the ecological point of view.

Though there was no evidence until recently, we must be able to presuppose these capacities also for diatoms. In fact, to all appearances they seem to occur in the form of indefinable clusters around certain generic subgroups such as several hundreds of «weak» taxa of lanceolate Nitzschiae.

Irrespectively thereof, what is needed, if we have to carry out a study which is based entirely on the typological classificatory principle? We should know that it is provisional, as a currently practicable classification, aware of its inherent shortcomings and restricted biological evidence. Unfortunately this classificatory principle has fallen into disrepute not only on theoretical grounds, but also because of the conceptless, extremely uncritical practice of many of its practitioners. One polemical species definition is: «A species is what the author understands by a species». That is not so very far removed from the current situation of contemporary species creation. It is not refutable and thus not scientific. In fact the principle of authority, which is a psychologically influenced aspect, plays an important role in the acceptance or rejection of opinions. Better known authorities often succeed with comparatively weak arguments, if such are even given in support of their decisions.

The Rules of the International Code of Botanical Nomenclature (ZCBN) can provide little assistance in deciding here. In particular they are not appropriate to direct how to discern between species. However, at least the priority principle offers a guideline. Already established taxa have priority - they are the reference point, a basis for later new descriptions. Each author should clearly present the features on which a new taxon differs from already established ones. It is essential that each diagnosis contains a differential diagnosis, something which has been largely unconsidered in practice. Not that thereby the problem of species definition in diatoms would be solved since even then description and the evaluation of characteristics remain overburdened with other subjective 
«judgements». But it would be possible to see to what extent a younger taxon should be «taken seriously», independent of the authority behind it.

When comparisons with apparently similar established older taxa are partially or entirely omitted, evaluation of the new taxon can be appropriately orientated. This is also the case where the differentiating characteristics given are exclusively those recognised as falling within the normal variability for populations of that genus.

How did this dilemma of the vast proliferation of taxa occur?

1. Numerous new taxa have been shown to be synonyms of older taxa because the authors had absolutely no knowledge of the latter.

2. The generally known «image» of similar older taxa is often unrelated to the type material, false or uncertain. Sometimes it is simply determined from illustrations, often secondhand.

3. It has been shown to be a great disadvantage, and of little sense to ignore the actual spectrum of variation by overtly choosing only quite specific (namely type-specimen-like) individual forms for diagnosis and illustration. Thus, other forms of the life-cycle or minor variations provided opportunities for the description of «new species».

4. The drawings of older taxa are often so inadequate or subjectively drawn that the intended form cannot be recognised with certainty again. Apart from this the sparse diagnostic information is often even less helpful because it may fit to numerous other taxa.

5. The probability that overlaps will occur in the characteristics used for the definition of taxa increases steadily. The network of taxa forms an increasingly narrower reticulate pattern. In particular in genera with few distinguishing characteristics there are always too few recognizable character combinations for new taxa.

How should conclusions be reached so that the typologically moulded diatom systematics can at least begin to satisfy the existing desire for order pragmatically? For a series of scientific disciplines, for instance applied hydrobiology, ecology, geology, information as to whether the recurrent appearance of a particular form really represents a definable species (in terms of population biology) or not, is no essential.
Nevertheless such practical functions cannot be fulfilled when unlimited possibilities for the creation of new taxa can be so excessively and uncritically exploited. One result is already apparent -the majority of hydrobiologists or ecologists are simply resigned to ignoring new taxa.

Therefore our suggestion: The taxonomist in practice will state continua and discontinua, he will describe as new what is apparently different and will synonymize what is supposedly identical. He will have to substantiate and to justify his decisions. His procedures will only be correct in terms of scientific theory, if his hypotheses are formulated in such a manner that they can be falsified (i.e. disproved) by new findings and -if so - can be replaced by new hypotheses. There are probably many more real species than we have recognized up to now, however, we assume diatomists have put much too many taxonomical species into circulation, and they continue to do so.

\section{ACKNOWLEDGEMENT}

The author is truly thankful to Dr. Eileen Cox for valuable linguistic help.

\section{BIBLIOGRAPHY}

Geitler, L., 1973. Auxosporenbildung und Systematik bei pennaten Diatomeen und die Cytologie von Cocconeis-Sippen. Osterr. Bot. Z. 122: 299-321.

Grant, V., 1976. Artbildung bei Pflanzen. P. Parey, Hamburg: 1-303.

Krammer, K. \& H. LAnge-Bertalot, 1986, 1988. Bacillariophyceae, 2/1, Naviculaceae; 2/2, Bacillariaceae, Epithemiaceae, Surirellaceae. In: Die SüBwasserflora von Mitteleuropa (begr. von A. Pascher), Stuttgart: p. 1-876, p. 1-596.

LANGE-Bertalot, H., 1977. Eine Revision zur Taxonomie der Nitzschiae lanceolatae Grunow. Die «klassischen» bis 1930 beschriebenen SüBwasserarten Europas. Nova Hedwigia 28: 253-308.

Lotsy, J.P., 1916. Evolution by Means of Hybridization. М. Nijhoff. The Hague.

Lotsy, J.P., 1925. Species or Linneon. Genetica 7: 487-506.

MaYr, E., 1967. Artbegriff und Evolution. Hamburg: 1-617.

MAYR, E., 1975. Grundlagen der zoologischen Systematik. Hamburg: 1-370. 


\section{RESUMEN}

\section{LA INVESTIGACIÓN BIOSISTEMÁTICA ACTUAL DE LAS DIATOMEAS Y SUS IMPLICACIONES SOBRE EL CONCEPTO DE ESPECIE}

En teoría deberían usarse dos categorías de especies de diatomeas: 1) las especies reales de acuerdo con la biología de poblaciones, y 2) las especies tipológicas y taxonómicas. En la práctica, sin embargo, pocas veces discriminamos entre estas categorías. Ésta es una fuente de problemas, surgida de conceptos inadecuados o confusos de especie. No existe evidencia alguna para suponer que la especie real no es la misma en las diatomeas que en las plantas superiores biparentales, es decir, una comunidad que comparte el mismo material génico. En las algas unicelulares, sin embargo, ambas categorías de especies a menudo se contradicen, dado que pocas características taxonómicamente significativas son distinguibles. Dos estrategias de investigación pueden ayudarnos a conseguir modelos comparables a los de las plantas superiores:

1) Encontrar, por medio de análisis de la población, la capacidad panmíctica real de las distintas «especies, variaciones polimórficas o razas». ¿Existen clones poliploides o poblaciones y complejos de clones híbridos uniparentales alrededor una especie sexual original? De ser así, las variaciones de tales grupos no deberían definirse como especies biológicas y sena necesario modificar este concepto.

2) Por otro lado, para obtener una aproximación a la especie real, los taxones desarrollados históricamente presuponen una reflexión mucho más crítica que los usados tradicionalmente. 